\title{
Customer Engagement with Social Media Bank Pages with Reference to Facebook
}

\author{
Mani R, Oveis PM, Ilankadhir M, Thiyagarajan S, Janakiraman S
}

\begin{abstract}
Indian banking sector is going through a massive transformation day by day with the advancement of Information and communication Technology and impact of digitization in the banking industry. After the core banking system, banks have moved further to reap the benefits of internet and mobile banking. In order to engage more customers anywhere and anytime without visiting the brick and mortar branches, the banks have now introduced the social media banking. Most of the people are already active in different social media platforms, so banks have grabbed that opportunity to reach people easily and provide services through social media. This paper has made an attempt to analyze the engagement of social media customers in different banks including public and private sector with reference to facebook bank page. The results show that most of the banks have presence on popular social media platforms. With respect to the engagement of customer to all facebook posts during the study period, public sector banks are posting more on their respective facebook page but the customers' likes as well as dislikes are more for SBI, ICICI and AXIS. In case of shares and comments, SBI and PNB have more and are increasing continuously as these two banks post more on their respective facebook pages. But with respect to customer engagement per facebook post during the study period, customers are engaged more with private sector banks. And it can be said that regarding overall customer engagement people are more engaged with private sector over public sector banks.
\end{abstract}

Keywords: Social media, customer engagement, facebook, digital banking, social media banking.

\section{INTRODUCTION}

Social media is that the collective of on-line communication channels dedicated to community-based input, interaction, content-sharing and collaboration in an efficient and quick way. Banks are providing variety of banking and financial products and services to the active social media customers through social media platforms like Facebook, WhatsApp, Twitter, Google+ etc. Modern day banking industry grabbed the opportunity of using the social media platform for offering their banking services to their present and potential customer base. Indian banking sector is nowadays coming up with more and more technological

innovation with the evolution of internet, mobile, computer

Revised Version Manuscript Received on 10, September 2019.

Mani R, Department of Banking Technology, SOM,Pondicherry University, Pondicherry, India. (Email: rmanigceb@gmail.com)

Oveis PM, Department of Banking Technology, SOM,Pondicherry University, Pondicherry, India.

Ilankadhir M, School of Management Studies, Sathyabama Institute of Science \& Tech, Chennai, Tamilnadu, India. (Email: mathikadhir@gmail.com)

Thiyagarajan $\mathbf{S}$, Department of International Business, SOM, Pondicherry University, Pondicherry, India.(Email: sthiyags@ gmail.com)

Janakiraman S, Department of Banking Technology, SOM,Pondicherry University, Pondicherry, India. (Email: jana3376@yahoo.co.in). and social media which helps to find suitable customer services and serve them in an efficient manner. The main objective of using social media platforms are to cater the needs of the customer, real time services through fund transfer etc,. While these banks are not only promoting their banking services through this platform, but also to enable the customer to understand the recent development taking place in the bank as well as in the the banking industry, helping customers resolve queries and coming up with announcements on the progress of the bank, results and so on. There are different tabs giving information on the milestones, various offers by the bank, product suite, events, contests, customer care numbers, testimonials, education materials on their branches and so on. Taking a step further, some Indian banks have recently launched a new type of banking service in social media platforms through which customers can transfer funds through social media platforms. This is to say it is easy to transfer money from one account to another account using their contact details, mail id, Whatsapp, Facebook or twitter account. This means that banks are using the social networking sites not only for promoting their brand or to study their customer expectations but also to provide like real-time banking services. In India internet users have grown enormously i.e., $90 \%$ as compared to the global i.e., a mere $19 \%$. As per the recent report, India has 462 million active users of which 153 million active social media users are there as compared to global 3.63billion of internet users of which 2.43 billion social media users. There are about 130 million active mobile users exist in India. During 2015, Indians social media users have rose by 23 percent which is very close to 26 percent of the Globe.

Banks to some extent succeeded in providing useful information through their social media pages and banking services through social media banking to their present and potential customers. But, how the customers are engaged to the bank's social media pages is most important. Customer engagement in general is a business connection between a customer and a company through various channels of correspondence. This connection can be reaction, interaction, effect or overall customer experience which takes place both online and offline. After 2000, the online communication has evolved in a multi dimension i.e., through like, share and follow. This stimulates the users to interact virtually; hence the organization takes this opportunity to connect with them by way of "likes", "shares" and "comments" for the purpose of achieving their goal. It has become a common practice for 
the organization to have social media platforms to interact with their customers. This in turn helps to build public rapport. As compared to the traditional marketing, the banking services have completely different approach with respect to marketing of their services. Social media platforms are used for the purpose of new product or service launch, their usages and features. So, in this context, this paper has made an attempt to see and analyse how the customers are getting engaged to the announcements which the banks are making through their social media platform pages.

\section{LITERATURE REVIEW}

This area has been extensively researched by various scholars in foreign countries but, scanty of studies has been found in Indian context. It has been found that, banks are now focusing more on social media trends, but to have the competitive advantage, they have to adapt more holistic social media strategy (Ibukun et al., 2016).

Balaram and Mohan (2018), in their study focused mainly on social media platforms of banks. The study says that through privacy policies, terms of use and technical functionality, social media platforms offer protection to the present and potential customers. It says if the customers are engaged with the social media platforms of their respective banks, they should move further to social media banking, as it provides proper protection to the customers.

Michael Veenswyk (2013), in his study found that banking industry is becoming famous due application of social media, as it has become a easiest channel to interact with the customers. The study also found that customers are more engaged with different social media platforms of banks, at the same time this cautions the bank about the risk of using different social media platforms because of the security issues associated with it.

Jason Kincy (2012), in his study found that banks are engaged in attracting the customers through social medial platforms. The study concluded by saying that the customers are engaged in social media platforms of banks so as to get the assistance and providing feedback etc,.

K. Hermkens (2012), revealed in his study that, as compared to the other sectors, banking and financial institutions lacks in adopting social media platform as a communication channel. In the recent past they are slowly picking up but the utility of the same is uncertain.

Gavin James (2012), concluded his study by saying that Social media platforms are considered as the best way to manage customer relationship especially in banking sectors. This paved the way for effective adoption of social media platforms.

\section{OBJECTIVES}

The objectives of the study are as:

1. To assess the presence of Indian commercial banks on different social media platforms.

2. To analyze the engagement of social media customers in different banks facebook page.

\section{METHODOLOGY \& RESULTS}

For the purpose of attaining the above objectives, the data were collected in two ways. The presence of Indian commercial banks on different social media platforms was collected in the first phase. Alongside with the help of "netvizz" applications the other data such as number of likes, comments, share and the number post and the fan followers of the respective banks were collected in the second phase. The sample banks include three public sector banks i.e., SBI, PNB and BOB and three private sector banks i.e., ICICI, HDFC and AXIS based on their market capitalization. The data was gathered in December, 2018 from the facebook page of the sample banks. More specifically, the data was gathered between 1st and 31st December, 2018. Trend analysis has been performed on the extracted data for the analysis purpose.

\section{PRESENCE OF INDIAN COMMERCIAL BANKS ON DIFFERENT SOCIAL MEDIA PLATFORMS}

Due to adoption of internet services and technological advancement the business communications have transformed enormously. This compelled banking industry to adopt innovative, client-oriented communication so as to interact with the customer about their product and services. This paved the way for the Social media to influence every organization especially the banking sector. Social media is one of the most viable methods of communicating with customers. In order to interact and deal in an efficient and frequent manner with the present customers, and also to capture the potential customers, Indian commercial banks have made presence on different social media platforms. It has become the fashion for every financial institution to have presence of social media, particularly banks interacting more with the customers. The social platform opens new opportunities for banks to provide information regarding the product and services in an effective way and at the same time to interact with the customers especially to assess their service capability and receive feedback from the customers. (Stone, 20019). There are some concerns also over the reliability of social media as a platform backs the customer relationship and the compliance with respect to industrial safety. (Jaser, 2010; Scarborough, 2010). Most of the Indian commercial banks have presence on different social media platforms. The table gives the clear picture of the presence of banks. 
Table 1. Presence of different banks on social media platforms

\begin{tabular}{|c|c|c|c|c|c|c|c|}
\hline Banls & Facebsok & I witter & Linkedin & Instagram & Pinterest & Googler & Youtube \\
\hline $\begin{array}{l}\text { Allahabad } \\
\text { Bank }\end{array}$ & Yes & Yes & Yes & No & No & No & No \\
\hline $\begin{array}{l}\text { Bank of } \\
\text { Indian }\end{array}$ & Yes & Yes & $Y_{n}$ & No & $N_{0}$ & So & No \\
\hline $\begin{array}{l}\text { Canara } \\
\text { Bank }\end{array}$ & No & Yes & Yes & No & No & 26 & Yes \\
\hline $\begin{array}{l}\text { Indian } \\
\text { Bank }\end{array}$ & Yes & Yes & Yes & Yes & No & No & Yes \\
\hline PNB & Yes & Yes & Yet & No & $\mathrm{No}_{0}$ & No & Yet \\
\hline SAI & Yet & Yet & Yes & $Y_{e i}$ & Yat & No & Yet \\
\hline $\begin{array}{l}\text { Bankaf of } \\
\text { Baroda }\end{array}$ & Yes & Yes & Yes & Yes & No & No & Yes \\
\hline Asis Bank & Yet & Yes & Yes & Yes & No & No & Yet \\
\hline $\mathrm{HDFC}$ & Yes & Yes & Yes & No & Yet & Yes & Yes \\
\hline ICICI & Yes & Yes & Yes & No & No & No & Yex \\
\hline Yes Banik & Yes & Yes & Yea & No & No & No & Yes \\
\hline
\end{tabular}

It is inferred from the above table that almost all banks have presence on the main three social media platforms which are facebook, twitter and LinkedIn except the Canara bank which does not have presence on facebook. With respect to Instagram, Indian bank, SBI, Bank of Baroda and axis bank have pages. SBI and HDFC have presence on Pinterest also while no other bank is on that platform. In case of Google+, only HDFC has a page their and others don't have pages on this platform. Lastly, in case of Youtube social media platform, almost all banks have their youtube channels except the two which are Allahabad bank and Bank of India.

\section{ENGAGEMENT OF CUSTOMERS WITH THE SOCIAL MEDIA PLATFORMS}

In today's technological environment, majority of the people gets engaged with others through different technological mediums and it has now stepped in banks also. So, the customers are reluctant to pay a visit to branches and prefer to communicate with their respective banks through different social media platforms. It has become easy for the banks also to share information through this medium. They are sharing the information related to different products and services to which customers engage with their likes, shares, comments etc. This study has taken the data of December month of 2018 and only one social media platform of selected banks has been analyzed.

Table 2. (A and B) Followers of banks facebook page (A)

\begin{tabular}{|l|l|}
\hline \multicolumn{1}{|c|}{ Banks } & \multicolumn{1}{|c|}{ Followers } \\
\hline ICICI & 5497029 \\
\hline HDFC & 2763179 \\
\hline AXIS & 3703759 \\
\hline SBI & 17871359 \\
\hline PNB & 424852 \\
\hline BOB & 1020876 \\
\hline
\end{tabular}

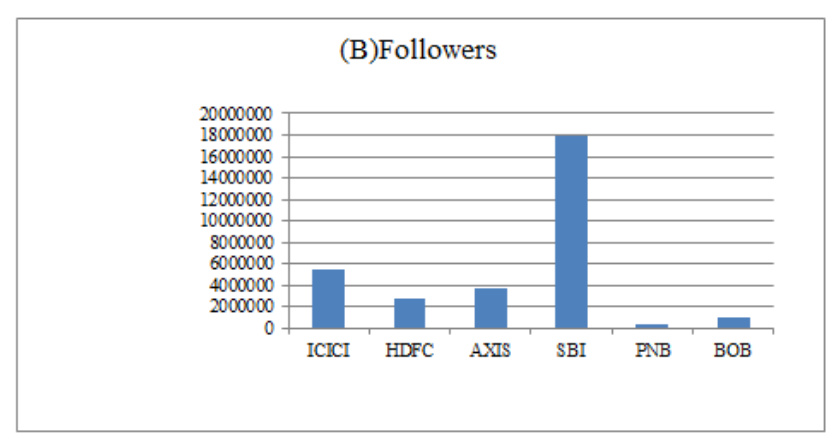

From the table.1 (A and B), we can see that SBI has the more followers followed by ICICI, AXIS, HDFC, BOB and PNB. Followers of SBI is more far from other banks, which are three times more than ICICI which is in second place and SBI is 17 times more than PNB which is in last place of selected banks.

Table 3. Customer engagement with the facebook page

\begin{tabular}{|c|c|c|c|c|c|}
\hline Banks & Pouts & Likes & Comments & Shares & Distikes \\
\hline SBI & 110 & 1421065 & 11197 & 9979 & 639 \\
\hline PNB & 99 & 35642 & 8939 & 5183 & 57 \\
\hline BOB & 51 & 44345 & 703 & 1122 & 15 \\
\hline ICICI & 32 & 932593 & 4112 & 2901 & 271 \\
\hline HDFC & 33 & 31514 & 3503 & 4797 & 254 \\
\hline AXI5 & 14 & 169317 & 3336 & 2943 & 323 \\
\hline
\end{tabular}

The above table depicts that, SBI have the highest number of updates (110 posts) on their facebook bank page which is followed by PNB, BOB, HDFC, ICICI and AXIS bank. It shows public banks are more active on facebook bank page than private banks. The engagement of the customers can be seen from the likes, comments, shares and dislikes to the respective posts of different banks.

\section{Interpretation}

The results obtained were visualized using line graphs to see the trend and has been interpreted. The trend has been seen for December, 2018 from the facebook accounts of six sample banks. The trend for the facebook of different banks can be seen as: 
Figure 1. Facebook Posts Trend

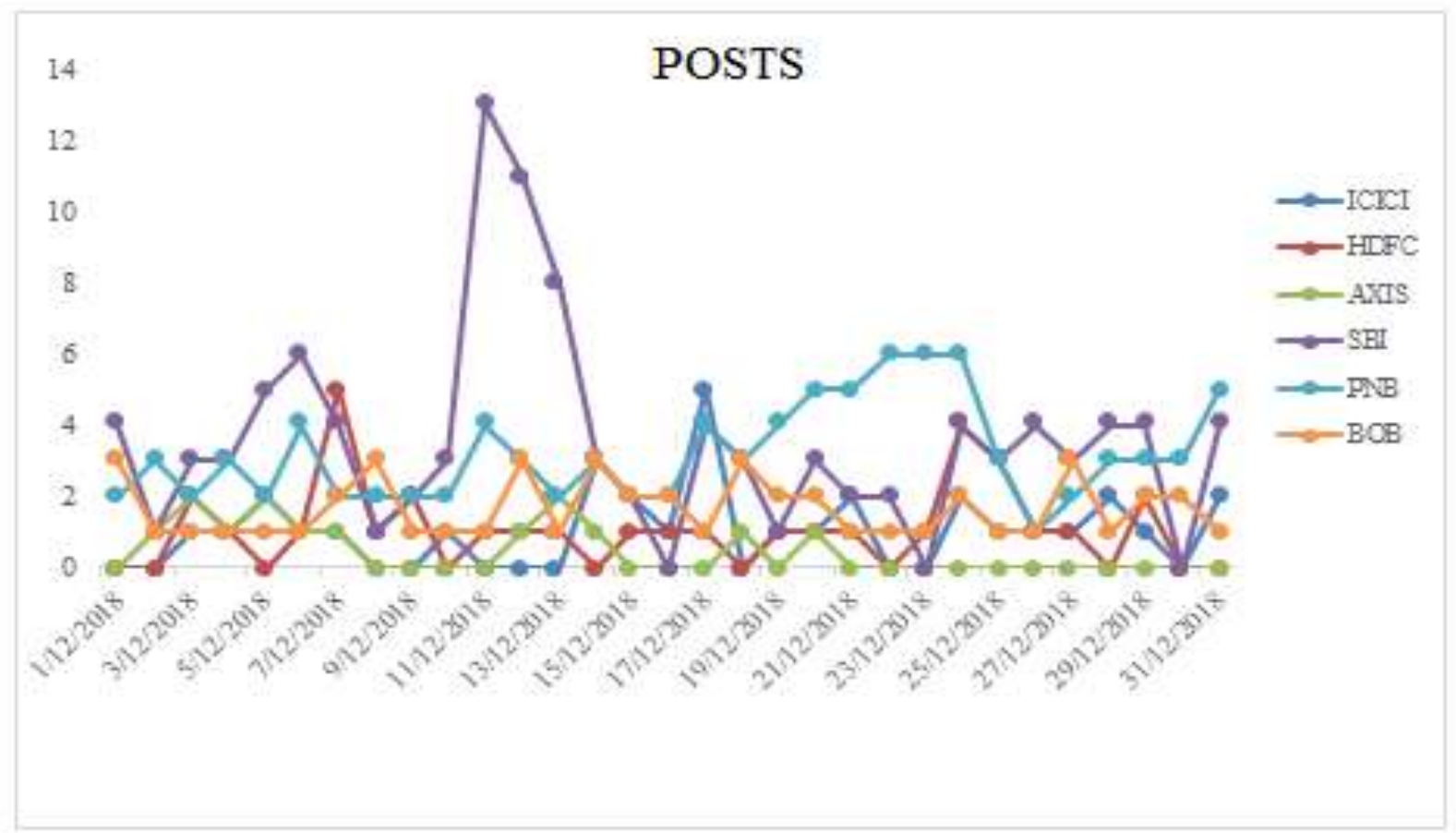

This figure shows the trend of different type of posts which these sample banks have posted on their facebook platform. As it can be seen from the figure that SBI has the highest number of posts posted on their facebook page followed by the PNB and BOB on a daily basis. Private sector banks have not posted more posts and a surge has been seen in ICICI and HDFC only on one day. Likewise, there is a surge in the number of posts on one day in SBI also.

Figure 2.Facebook Likes Trend
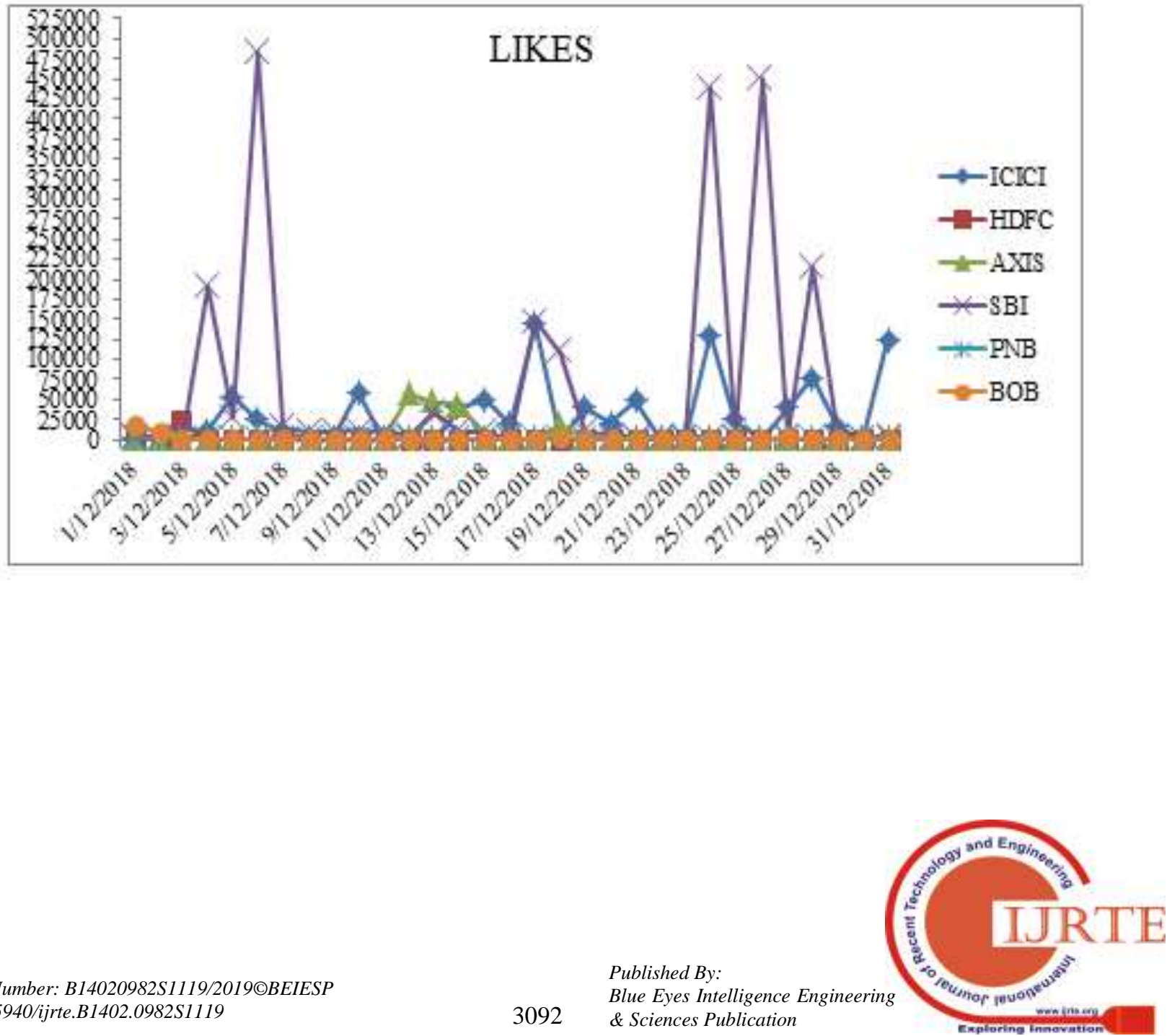
In the above figure of facebook likes on the posts posted by respective banks on their facebook platform, only SBI, ICICI and AXIS have the highest number of likes among all the six sample banks. It seems that customers are more engaged to facebook page of these three banks only.

Figure 3.Facebook Comments Trend

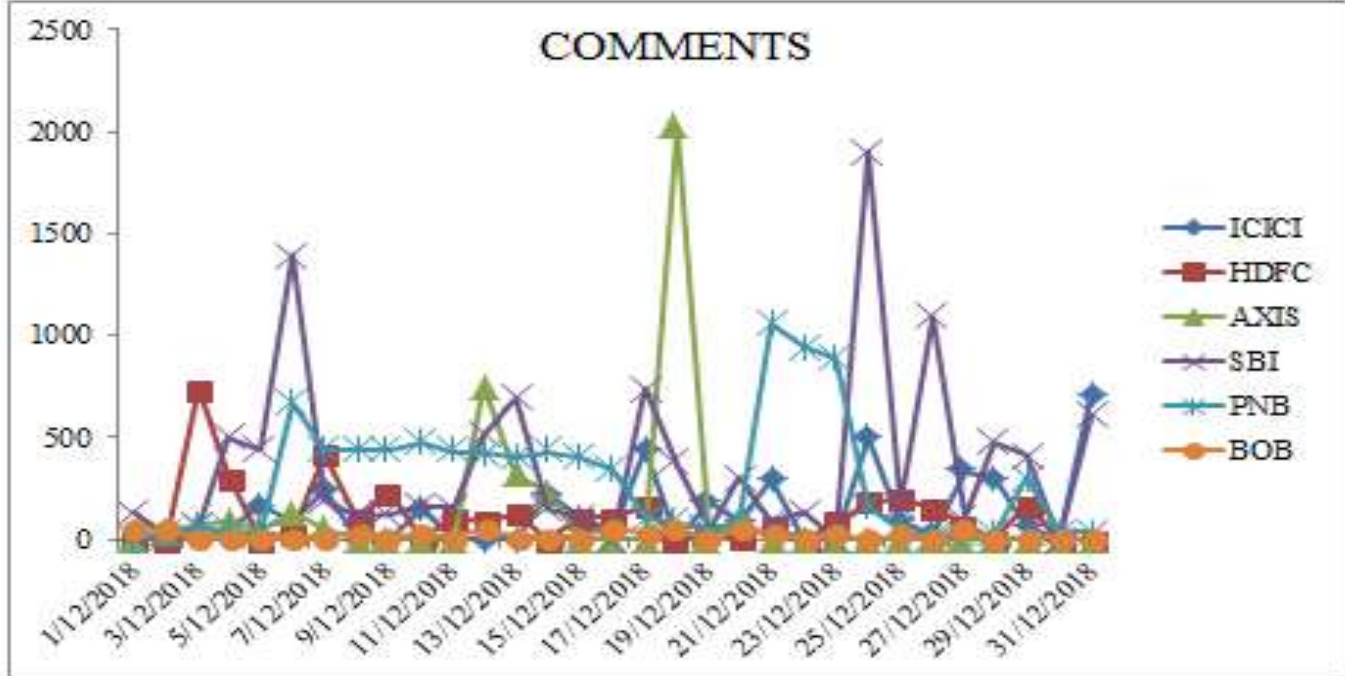

can be said that customers were more engaged with SBI and

In the above figure, it has been seen that SBI and PNB PNB as they have posted more post. have more fluctuations than among other selected banks. And a huge surge has been seen in AXIS bank on only one day. It

Figure 4.Facebook Shares Trend

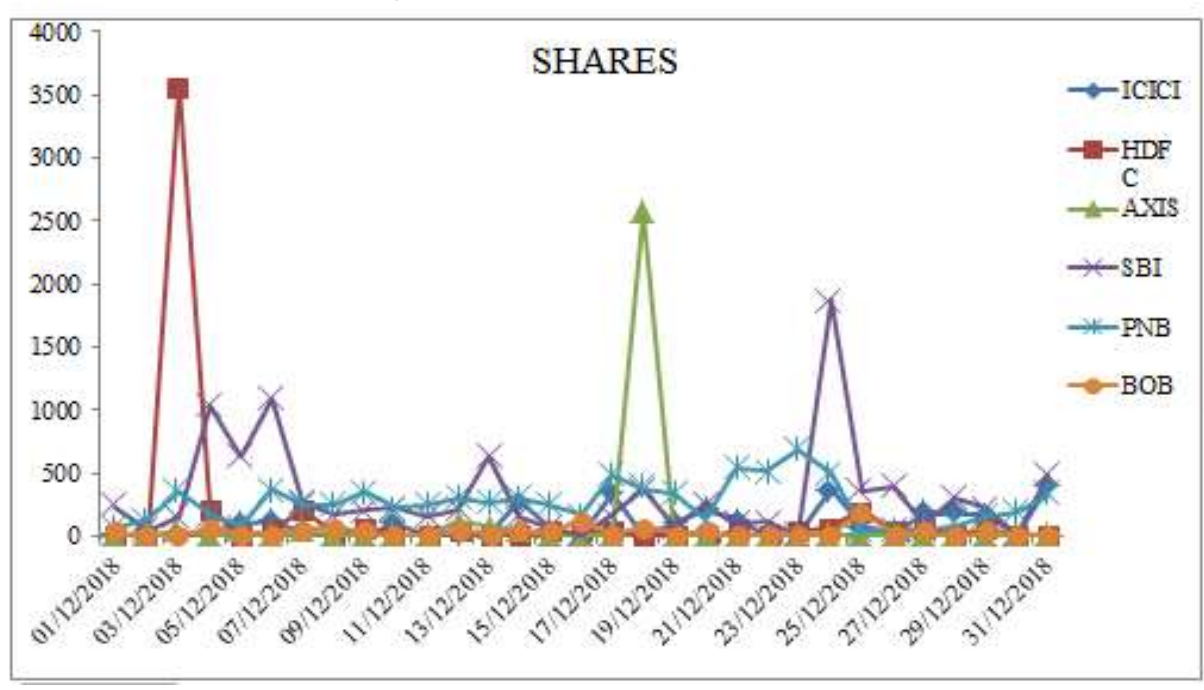

In the above figure it has been seen the trend of shares of those posts which were posted by the banks facebook pages. The customers have been seen more engaged with SBI and PNB by sharing their content to others as they have more post on their Facebook page. There has been seen a surge on only one day for HDFC and AXIS Post but for rest of the days the shares were almost below 300 for HDFC, AXIS, ICICI and BOB banks. 
Figure 5.Facebook Dislikes Trend

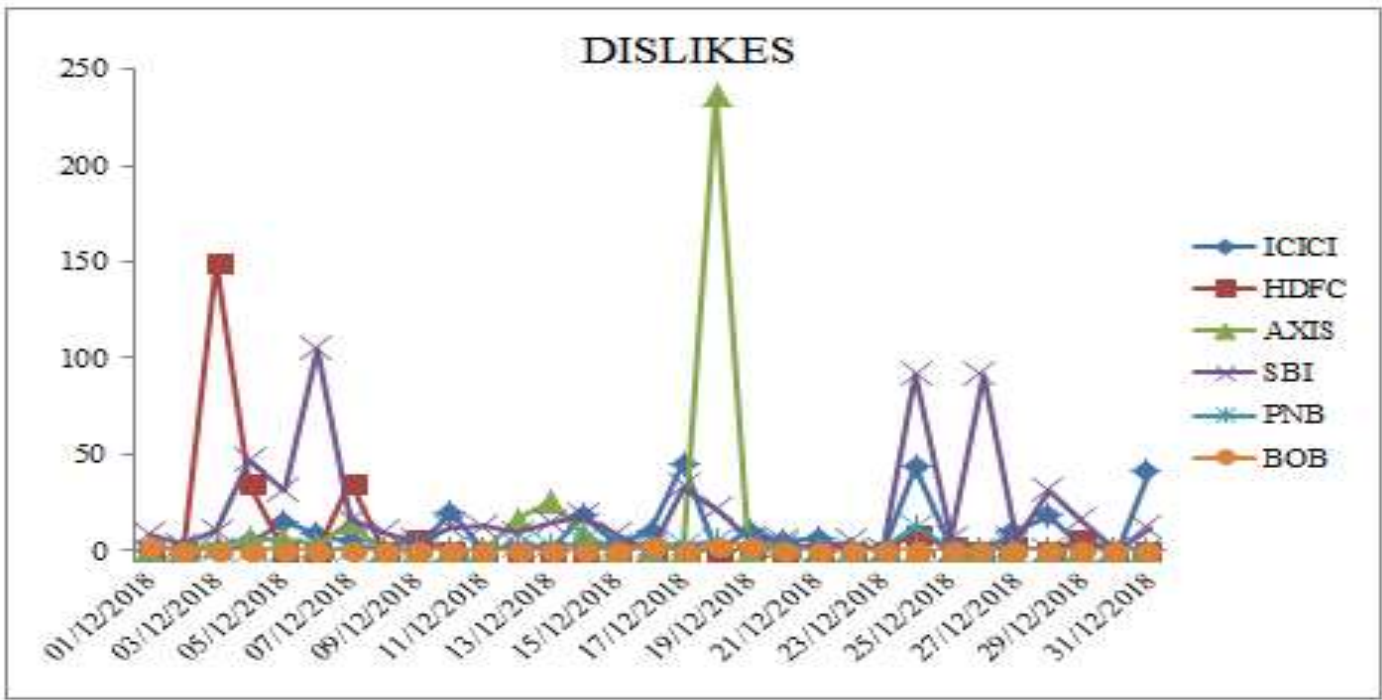

The above figure shows that mostly the dislikes have been

the above that more customers are engaged with SBI and given to SBI and Private sector banks. It can be inferred from Private sector banks even though other two Public sector banks have more no. of posts than Private sector banks.

Figure 6.Facebook Likes per Post

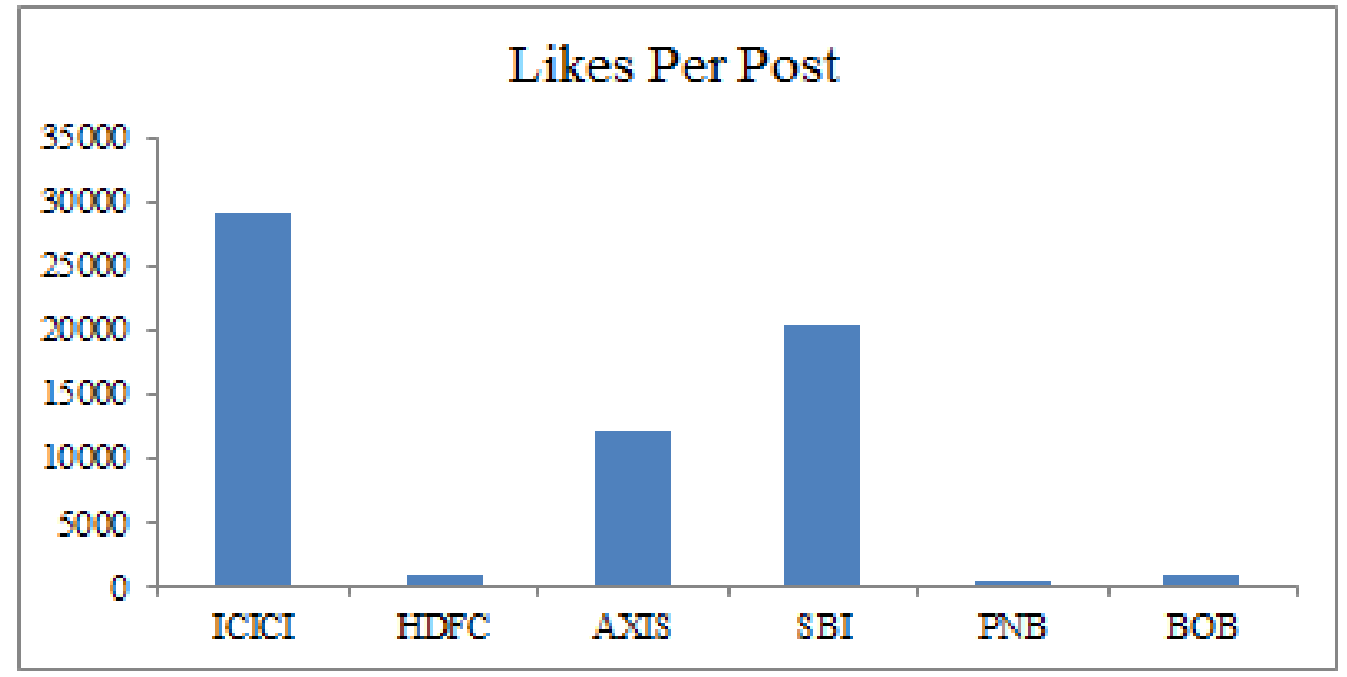

In the above figure, the average likes per post of those posts which were posted by the banks facebook pages has been observed, from which we can infer that more customers are engaged with ICICI followed by SBI and AXIS bank. Among other three banks HDFC have more customer engagement than other two public sector banks. In other words, customers of private banks are more active on the post of Bank Facebook page than the public banks.

Figure 7.Facebook Comments per post

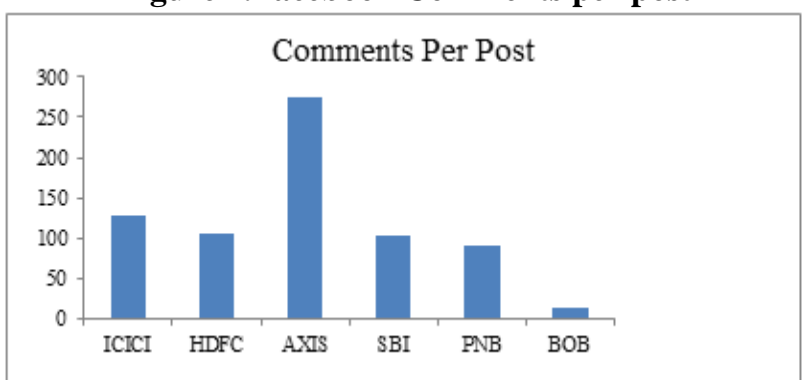


In the above figure the values of average Comments per post has shown that, Private sector banks have got more customer engagement than Public sector bank even though more posts have come from Public sector banks facebook pages.

Figure 8.Facebook Shares per post

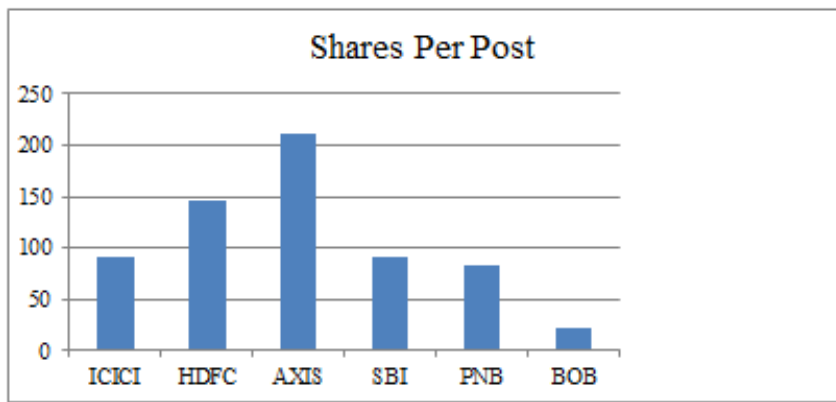

From the above figure, average shares per post is more for AXIS followed by HDFC, SBI, ICICI, PNB and BOB and the difference between SBI and ICICI is only 0.06, which is not a considerable difference also.

Figure 9.Facebook Dislikes per post

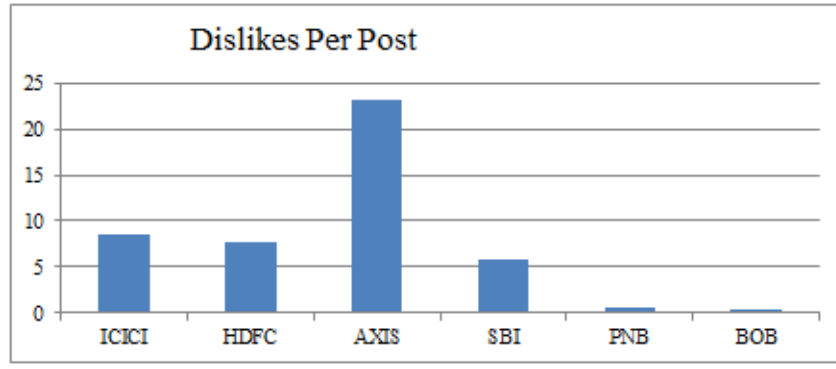

From the above figure, average Dislikes per post are more for AXIS, ICICI, HDFC followed by Public sector banks. It can be said that more customers engage with private sector banks by post wise from above three variables i.e. Likes, Comments and Shares., dislikes by post also more for Private sector banks.

\section{CONCLUSION}

Social media platform has become a prominent medium of sharing information and getting the quick feedback regarding the products and services. In the concluding statements, it can be said that almost all the Indian commercial banks have presence on different popular social media platforms. Regarding the engagement of the social media users, most of the customers are actively engaged with their respective bank's social media platforms. It has been found that by bank side engagement with customers, public sector banks are more active in posting on their respective Facebook page as compared to the private banks. As against this customers of private sector banks are more interactive than the public sector banks. Further it is explored that SBI is leading among other banks which is considered as a tough competitor to private sector banks especially in relations to receiving average likes per post and average shares per post. So, as a good competitor to private sector banks and having more followers, SBI can get more customer engagement than private sector banks if SBI provides more customers' attractive post like private sector banks provides.

\section{REFERENCES}

1. Afolabi, I.T., Ezenwoke, A.A., and Ayo, C.K., (2016), 'Competitive analysis of social media data in the banking industry’, Int. J. Internet Marketing and Advertising, Vol. X.

2. Babu, P.B., and Babu, CH., (2018), 'Role and impact of social media on banking industry', International Journal of Commerce and Management Research, Vol.4, pp-56-61.

3. Alves, H., Fernandes, C., and Raposo, M., (2016), 'Social media marketing: a literature review and implications, Psychology and Marketing, Vol.33(12), pp-1029-1038.

4. Kirakosyan, K., (2015), 'Social media usage in banking industry and its managerial view: case study for Mexican banking system', Journal of Economic and Social Development, Vol. 2(1)

5. Mishra, S., and Tyagi, A., (2015), 'Understanding social media mindset of consumers: an Indian perspective', Journal of Information Systems and technology Management, Vol. 12(2), pp-203-218.

6. Mitic, M., and Kapoulas, A., (2012), 'Understanding the role of social media in bank marketing', Marketing Intelligence and Planning, Vol. 30(7), pp-668-686.

7. Stone, M. (2009), "Staying customer-focused and trusted: Web 2.0 and Customer 2.0 in financialservices", Database Marketing \& Customer Strategy Management, Vol. 16 No. 2, pp. 101-31.

8. Jaser, J., (2010), 'The case against social media in banking', New Jersey Banker, Dec., pp-26-31.

9. Scarborough, M. (2010), "Proceed with caution", US Banker, Vol. 120 No. 8, p. 24.

10. Vemuri, A. (2010), "Getting social: bridging the gap between banking and social media", GlobalFinance, Vol 24 No. 5, pp. 20-1.

11. Pannunzio, C. (2008), "Leverage the power of social media", Journal of Financial Planning, Vol. 8 No. 6, pp. 6-8. 